\title{
REGIONAL INSTITUTIONALISM IN SOUTHEAST ASIA
}

\author{
Mindaugas Norkevičius \\ Vytautas Magnus University \\ Faculty of Political Sciences and Diplomacy \\ Departament of Political Sciences \\ Gedimino 44-201, 44246 Kaunas \\ E-mail: norkevicius.mindaugas@gmail.com
}

Received on 20 January, 2014; accepted on 5 March, 2014

doi:10.13165/SMS-14-6-1-06

\begin{abstract}
This article demonstrates how regional institutions in Southeast Asia help solving common problems (political, security, economic, environmental, social, cultural, ect.), form common rules, norms and customs for cooperation, create the agreed agendas for regional issue management. In the article, using a neoliberal institutionalism approach, it has been ascertained what factors influence the effectiveness of the selected intergovernmental regional institutions in Southeast Asia, facilitate the regional response and reaction to common regional (economic, security, political, social) challenges. Regional agenda usually depends on actors, regional order (power structure within the region) as well as on regional identity. Institutions legitimate the region, but on the other hand, regional identity legitimates institutions.

Theoretical paradigm in the article is neo-liberalism. Two requirements should be fulfilled in order for neo-liberal institutionalism to be aplicable: (1) there should be common interests (as gains are achieved through cooperation), (2) it is required that variations in the degree of institutionalization would exert substantial effects on the state's policy.

The article analyzes how regional institutions in Southeast Asia form the possibility for the region to emerge as a single actor in the international system. Analysis of multi-
\end{abstract}

Socialiniu mokslų studijos / Societal Studies

(C) Mykolo Romerio universitetas, 2014

(C) Mykolas Romeris University, 2014
ISSN 2029-2236 (print), ISSN 2029-2244 (online) http://www.mruni.eu/lt/mokslo_darbai/SMS/ http://www.mruni.eu/en/mokslo_darbai/SMS/ 
purpose regional institutions in ASEAN demonstrates how organization serves the purpose of enhancing the efficiency of transactions among states, but the ambiguity in them also functions as a tool to manage distribution of power.

Keywords: regionalism, regional institutionalism, Southeast Asia, international organizations.

\section{Introduction}

The proliferation of regional groupings of Asian states is perhaps the most notable and consequential feature of the international landscape to take shape from the second half of the 20th century, and especially since the Cold War's end. Regional institutions in Asia have expanded in number and, due to frequent overlap in a given territory, they have begun to coordinate their activities. Since the end of the Cold War, regional institutions have deepened their integration and expanded their roles and tasks that they can undertake. If current trends continue, relations within and between institutionalized regional grouping are likely to be the defining elements of the international system in the 21 st century.

Theoretically, communication and socialization, sharing of information, increase of the consensual knowledge, growth of power and security through the concentration of resources and collective actions should be facilitated in regionalism. Regional actors have a deep interest in politics, economic and security areas in their respective regions. However, regional institutions vary in their capacities and sometimes are unable to fulfill the roles and tasks that they have been given.

Regional organizations institutions are a necessary part of organization studies because they supply most of the actors who are engaged in the policy-making process. Moreover, institutions are key variables in understanding how a regional organization works because the integration process itself is shaped by their patterns of contestation and cooperation. The object of the research is factors that determine effectiveness of the regional institutions in Southeast Asia. The aim of the research is as follows: using a neo-liberal institutionalism approach to ascertain what factors influence the effectiveness of the selected intergovernmental regional institutions in Southeast Asia. Following the objective, these tasks should be accomplished: (1) to survey theoretical perspective on neo-liberal institutionalism; (2) to explain regional institutionalism in Southeast Asia; (3) to follow new regional institutional structures in the Southeast Asia; (4) to describe factors of the effectiveness on regional institutions.

The article is a case study, it analyzes one region's (Southeast Asia) case. The main research objective and tasks have influened the selection of descriptive data analysis and comparative approaches. Descriptive data analysis method allows partially to display the factors affecting the effectiveness of regional organizations, analyzes separate regional organizations and relations between them and other international actors, according to neo-liberal institutionalism. Comparative method allows to 
focus on certain common aspects of selected regional organizations and to use observed commonalities or variations among the cases to draw general conclusions about the variables under study. In the article, descriptive method helps to reveal the circumstances of the analyzed developments and trends.

Theoretical basis for the review of the regional institutions has been analyzed by the following authors: A. Paasi, A. Acharya 'Constructing a Security Community in Sounteast Asia', A. Johnston, J. Eriksson, D. Bigo, R. Keohane 'International Institutions and State Power'. The book discusses the theoretical regional institutions, regionalism process models, according to neo-liberalism, which is based at work. In the research, the following journals have been used: 'Foreign Affairs', 'International Organization', 'Survival, 'Pacific Affairs', 'Asian Survey', 'Contemporary Southeast Asia', 'International Studies Review', 'Stanford Journal of East Asian Affair'. These articles contain research in Southeast Asian regional institutions and present effective examples of processes.

The first part of the analysis is based on theoretical paradigm of the neo-liberal institutionalism. The second part describes regional institutionalism in Southeast Asia. The analysis has been performed determining reasons limiting regional institutions effectiveness. The third part of the analysis is new institutional structures in the Southeast Asia according to neo-liberalism. The logic of comparison must include both elements of similarity and difference; therefore, in order to derive the greatest values from the analysis process, there have been chosen three different in their purpose, development, member and issue scope - regional organizations institutions. The article is completed with conclusions and remarks on Southeast Asian institutionalization.

\section{Theoretical paradigm of the neo-liberal institutionalism}

Neo-liberal institutionalists view regional formations as more intermediary bodies, erected by member states primarily to solve collective action problems. Regional institutions are crafted by egoistic states looking to liberalize the marked and benefit from the joint giants associated with trade creation. Institutions facilitate cooperation and liberalization through building more stable expectations of reciprocity, increasing transparency and lowering information costs, and setting up mechanisms to resolve disputes and enforce agreements.

Institutions do not, however, change the identity and interests of the state, nor do they alter its essential functions and competencies. Instead, neo-liberal institutionalism rests on micro-economic foundations and a state-centric, rationalist approach to behavior. In part because of its reliance on classical trade theory and more recent work on public goods and strategic bargaining, neo-liberal institutionalists assign institutions less importance than do functionalists; in effect, regional institutions operate at the margins to generate increases in trade and wealth that would otherwise go unrealized. 
Neo-liberal institutionalism has been the most influential theoretical approach to the recent study of international co-operation: it represents a highly plausible and generalizable theory that allows better understanding of the resurgence of regionalism ${ }^{1}$. Analysis of institutionalism is based on a number of core arguments. Firstly, due to increasing levels of interdependence, it manifests an increased 'demand' for international co-operation.

Institutions are defined as purposively generated solutions that are oriented towards collective action problems of different kinds and, according to Robert Keohane, international regimes to mythical positions of authority over states are not elevated by the institutionalism, on the contrary, such regimes are established by states on the purpose to achieve their goals. When dealing with dilemmas that are associated with coordination and collaboration under conditions of interdependence, governments ask international institutions to enable them in order to achieve their interests that are limited to collective actions ${ }^{2}$. Norms, rules and institutions are established due to the fact that they help states to deal with common problems and are the basis for welfare.

Neoliberal institutionalism is heavily statist phenomenon. It is characterized by the means, which are perceived by states as rational and leading to co-operation. While dealing with neoliberal institution, state is defined as an effective gatekeeper that guards the gate between domestic and international space. Indeed, this approach emphasizes how the role of state is strengthened by successful collaborative management of common problems. Thus, rational institutionalism is seeking how to retain neo-realist assumptions, but it does not agree that they do preclude cooperation.

Institutions are important due to the benefits they provide and due to their authority on the players calculations and the ways in which states define their interests. Provision of information, amount of transparency and monitoring, reduction of transaction costs, development of convergent expectations and the productive use of issue-linkage strategies help to achieve this. Particular attention is paid to the number of players; the extent of the states' involvement in an ongoing process of co-operation (the idea of repeated games of 'iteration' and the importance to lengthen the shadow of the future); and effectiveness of the mechanism that is oriented against fraud (the fraud that is considered as the main obstacle to co-operation rather than, as neorealist argue, distributional structure and concern for relative gains).

Institutionalism theories concentrate on the ways in which strategic interaction may lead to the emergence of cooperation in a given area of international relations. As it was mentioned earlier, the dominant trend that prevailed in the 1970s and 1980s

1 Kochane, O. R. International Institutions and State Power. Boulder, Colorado: Westview, 1989, p. 27.

2 Kochane. O. R. Institutional Theory and Realist Challenge After the Cold War. Baldwin, D. (ed.). Neorealism and Neoliberalism. NY: Columbia UP, 1993, p. 274. 
was the objective to apply this approach to non-region-specific questions (mainly in the economic and environmental fields, but also putting little emphasis on security regimes). However, institutions have increasingly turned their attention to the EC, highlighting the extent to which even institutionally complex regional arrangements are based on an evolving set of intergovernmental negotiations between the major states. Also, they have pointed to the reassertion of the European national governments' control after the early movement in the direction of supranationalism and the creation or strengthening of intergovernmental practices and institutions ${ }^{3}$.

When applied to the other examples of regionalism, institutionalism theory would allow to identify the ways in which processes of regionalization and regional economic evidence: firstly, this should be material problems and, what Richard Cooper has called, 'international policy externalities' that require collective management; and secondly, this should be the incentives for reducing transaction costs and facilitating intra-regional linkages ${ }^{4}$. It is expected that both would lead to the expansion of formal or informal interstate cooperative institutions. Thus, for example, the dilemma faced by the USA and Mexico in the NAFTA process was not whether they should move closer to each other, but rather whether the management of increasingly complex and dense economic, environmental and societal interdependencies that had emerged over the past forty years should be formalized and institutionalized, or left to ad hoc political bargaining. Equally, the increased emphasis on political regionalism in Asia Pacific region reflects the need for institutionalism theory to 'mange' the increased levels of economic interdependence that had grown up across the region.

According to Peter Petri, the importance of a particular partner in a country's transaction is likely to be closely related to the country's investments in the linkages with that partner. Therefore, it is not surprising that a wide array of regional initiatives have recently emerged to address the new issues generated by East Asian interdependence. When viewed from the analytical perspective, these initiatives can be seen as attempts to reduce transaction costs in regional trade, international trade frictions, and to impose regional economic forces against external economic challenges 5 .

From an institutionalism perspective, the emergence of regional security regimes (such as OSCE or ASEAN Regional Forum, or the network of confidence-building measures in South America) should not be viewed in terms of balance of power or alliance formation. Rather, they have been established and will survive because of the benefits they provide: they facilitate communication, spread of information,

3 See, e.g., Kochane, O. R., and Hoffimann, E. (eds.). The New European Community: Decisionmaking and Institutional Change. Boulder, Colorado: Westview, 1991, p. 129.

4 Cooper, R. N. Interdependence and Co-ordination of Policies. Amsterdam, 1985, p. 46-47.

5 Petri, A. P. The East Asian Trading Block: An Analytical History. In: Frankel, J. A., and Kahler, M. (eds.). Regionalism and Rivalry. Japan and the United States in Pacific Asia. Chicago: Chicago UP, 1993, p. 42. 
transparency; they reduce general threat perceptions and worst-case thinking; and they undercut self-fulfilling prophecies that lie at the heart of the security dilemma.

Finally, regional cohesion would emerge. On this view, they would emerge not due to grand proposals to create new federal structures, but due to the way that allows formation of an increasingly dense network, which is possible because of individual or issue-specific co-operation concentrated on each new issue and embedded in a larger and more complex whole.

\section{Regional institutionalism in Southeast Asia}

Neo-liberal institutionalism has a considerable explanatory power and tracks well with the evolution of the EU, the NAFTA and the ASEAN. Substantial increases in intra-regional trade preceded the formation of regional institutions in Europe, North America and the Pacific. These increases were principally market-driven and facilitated by proximity, historical and cultural ties, and other non-institutional factors. Institutions emerged as a greater interdependence created a need for them. The gradual proliferation of the EU's institutional infrastructure and its autonomous and supranational character best fit a neo-liberal account. The institutions of the EU have taken on a life of their own, surpassing member states in the ambition of their agenda for integration.

Global and regional institutions can and should work together in order to promote international peace and security. Regional statesmen have a deep interest in conflict management in their respective regions, and in most cases they can help to guarantee legitimacy, share local knowledge and experience, and some resources, especially in the form of personnel. However, there are several limitations, such as lack of mandate, the difficulty of maintaining impartiality and forcing common positions, limited recourses and organizational shortcomings.

Southeast Asian regional institutions have difficulties in explaining the legacy of colonialism. Historically, every East Asia country was colonized or dominated by foreign powers. Colonialism oriented the colonized countries, politically and economically, toward their imperial rulers rather than each other, a separation that continued for centuries (in some cases) until the post war period of World War $\mathrm{II}^{6}$. Nonetheless, the countries of the region remained separated - both internally and from each other - by ethnicity, languages, religion and culture. Southeast Asian states have been concerned regarding establishment of viable, politically legitimate governments. This concern is the most important factor that allows finding out how far regional states are determined to go on the purpose to establish and encourage effective regional institutions. 
Why did Southeast Asia need an intergovernmental organization? According to Thanat Knhoman, writing 25 years since he hosted the first meeting of five foreign ministers who affixed their signatures to the Bangkok Declaration, the most important reason was the fact that after withdrawal of the colonial powers, there would evidence a power vacuum which could attract outsiders who could step in for political gains. He believed that due to discouragement of any form of intraregional contact that has been made from the side of the colonial statesmen, the idea of neighbors working together in a joint effort was thus encouraged ${ }^{7}$.

The Bangkok Declaration proclaimed that the Southeast Asian countries share a primary responsibility for strengthening the economic and social stability of the region and ensuring their peaceful and progressive national development. The founders' model was the European Economic Community ${ }^{8}$. But even before it could get itself organized for economic cooperation, major political and security issues began to preoccupy the ASEAN: the intensifying Vietnam War, the subsequent occupation of Cambodia by Vietnam and the Cambodian peace process. This period stretched to about two-thirds of ASEAN's existence.

From the beginning, the five founding members - Indonesia, Malaysia, the Philippines, Singapore and Thailand - agreed that the ASEAN should be open to all Southeast Asian states. But the immediately succeeding years were not conducive for this to happen. It took more than three decades for the organization to realize the vision of bringing all Southeast Asian countries under the framework of one regional cooperation. The final consolidation of the ASEAN into ten member countries was a function of several factors - domestic, regional and global. Brunei Darussalam joined after it became independent, while the end of the Cold War and the political normalization in Cambodia paved the way for the entry of the Indochinese states Vietnam, Laos, Myanmar and finally Cambodia (see Annex 1).

The contemporary discussion of the ASEAN is focused on the extent of successful creation of the ASEAN's regional identity in Southeast Asia'. There is the unconvincing evidence which states that the ASEAN is the foundation of a strong regional identity ${ }^{10}$. ASEAN's limited ability to create such an identity is an expression of an inherent tension between state sovereignty and regionalism. ASEAN's members designed it to maintain and promote conceptions of sovereignty. There are numerous examples of ASEAN's members acting in ways that undermine the unity and the principles of the organization, but there also are examples of the ASEAN as the

7 Khoman, T. ASEAN: Conception and Evolution. Singapore: Institute of Southeast Asian Studies, 1992, p. 5-6.

$8 \quad$ Ibid., p. 6.

9 Acharya, A. Constructing a Security Community in Sounteast Asia. London: Rouledge, 2001. p. 65 .

10 Nischalke, T. Insights from ASEAN's Foreign Policy Co-operation: The “ASEAN Way", a Real Spirit or a Phantom? Contemporary Southeast Asia. 2000, 22 (1): 89-91. 
institution that accepts the compromise of its stated goals in order to accommodate the sovereign concerns of its members.

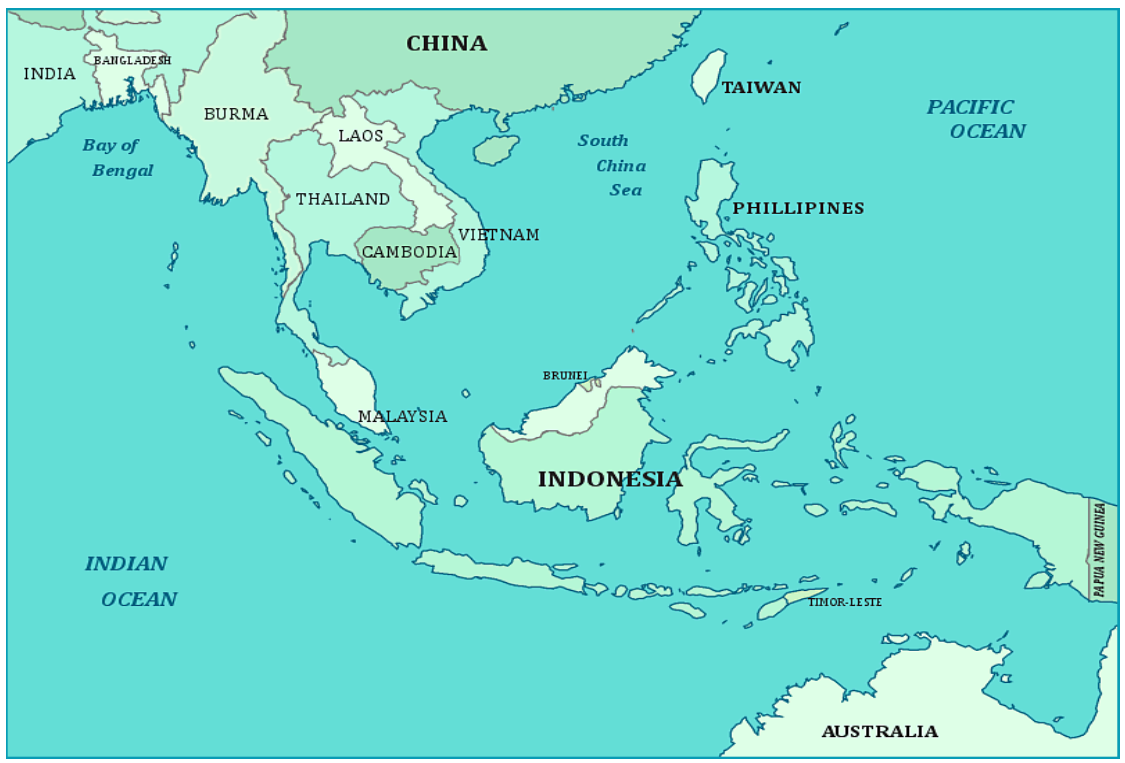

Source: Map of South-East Asia. <http://www.world-maps.co.uk/continent-map-of-south-east-asia.htm>.

Annex 1. Map of Southeast Asia Region

Since its inception, the ASEAN was a non-aggression pact between its members and represented a political united front against communist insurgency. Its initial mission was interested in creating space for its members, which would allow them to construct themselves as states ${ }^{11}$. The ASEAN promoted a vision of regional order that emphasized the importance of national sovereignty, prevention of intervention in the member's internal affairs and affirmed Southeast Asia's right to be free from the intervention of the great powers. At the same time, however, most of the member states perceived ASEAN's declaratory positions as potential impediments to their actual pursuit of security and sovereignty. The realization of the sovereign ideal that was symbolized by the ASEAN often was not the most effective way to protect sovereignty (more comprehensive information about the ASEAN's institutional structure is represented in Table 1).

11 Narine, S. Explaining ASEAN: Regionalism in Southeast Asia. Boulder, Colorado: Lynne Rienner, 2002, p. 9. 
Table 1. ASEAN's institutional structure

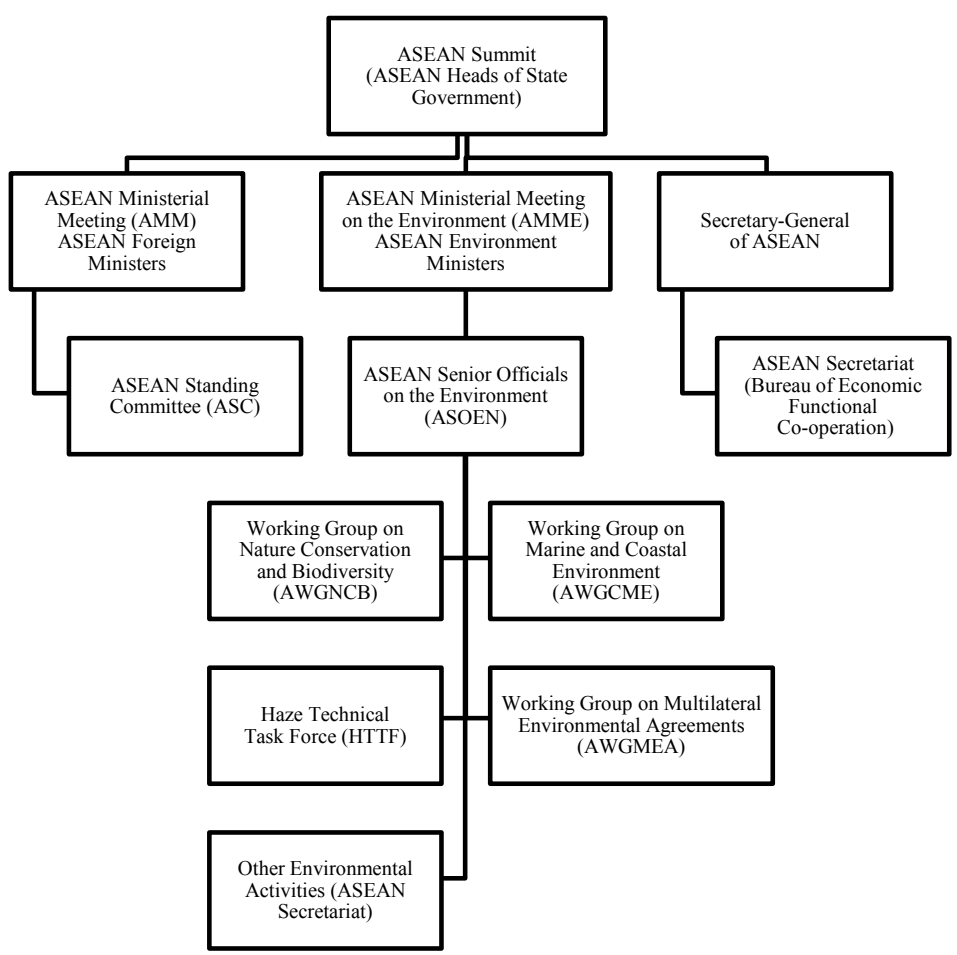

Source: compiled by the author.

ASEAN's institutional initiatives and practices were adapted to fit or, at least, not to conflict with its member's self-interests. For example, according to the ASEAN Declaration of 1967, a long-term goal of the ASEAN was the removal of foreign military bases from Southeast Asia. However, most of the ASEAN states were dependent on the security guarantees, which were supposed to be ensured by outside powers (Britain and the USA) to help project their sovereignty. Ambiguity and not mentioning the time period given to achieve this goal was a necessity in the Declaration. Similarly, political compromise was the reason why ASEAN's Zone of Peace, Freedom and Neutrality (ZOPFAN) emerged. The ZOPFAN was introduced by Malaysia, because the latter wanted Southeast Asia to be neutralized by the agreement between the great powers.

The other ASEAN states rejected the Malaysian proposal, because most of them relied on their external allies for security. Indonesia was the country that defined China as the major threat to the region, it refused to endorse a plan that would legitimize a Chinese role in the regional affairs. The ZOPFAN that emerged due to the ASEAN's deliberations was a long-term goal. No real limitations were imposed upon 
its members ${ }^{12}$. Corporate decision-making process, which encourages consultation and consensus building, is the way of the ASEAN. The members are not enforced to make such the decisions that might be in conflict with their national interests. Finally, the ASEAN has kept the ASEAN's Secretariat, which manages the group's activities, understaffed and overworked. ASEAN's major initiatives are conceptualized in the ASEAN's secretariats, which are established in the foreign ministries of each member state. The control of the ASEAN decision-making process is maintained in every member state.

Four new members (Vietnam, Cambodia, Laos and Burma) were added to the ASEAN during the post-Cold War period. Moreover, it has increased the scope of its activities by establishing the ASEAN Regional Forum (ARF) and the ASEAN Free Trade Area (AFTA) (more comprehensive information about free trade agreements is represented in Table 2). These efforts, in part, have been made in order to maintain and to enhance the ASEAN's effectiveness as a voice that speaks in the name of Southeast Asia, part of the ASEAN's appeal to its new members, however, there also was the promise that the organization could improve its international position, but it had to be guaranteed that such the position, as a matter of principle, would not intervene in their internal affairs.

Table 2. ASEAN countries' Free Trade Area

\begin{tabular}{|c|c|c|}
\hline Intra-East Asia FTA & Membership & Status \\
\hline $\begin{array}{l}\text { ASEAN Free Trade Area } \\
\text { (AFTA) }\end{array}$ & ASEAN-10 & Implemented \\
\hline $\begin{array}{l}\text { ASEAN-Japan Comprehensive } \\
\text { Economic Partnership } \\
\text { (including bilateral) }\end{array}$ & ASEAN-10, Japan & $\begin{array}{c}\text { Framework agreement signed in } \\
\text { Oct } 2003 \text { (CEP outline negotiations } \\
\text { begin in April 2005) }\end{array}$ \\
\hline $\begin{array}{l}\text { ASEAN-China Comprehensive } \\
\text { Economic Co-operation } \\
\text { (including FTA) }\end{array}$ & ASEAN-10, China & $\begin{array}{l}\text { Framework agreement signed in } \\
\text { Nov. 2002; Early Harvest Programme } \\
\text { and Trade in Goods Agreement } \\
\text { implemented }\end{array}$ \\
\hline ASEAN+3 & $\begin{array}{l}\text { ASEAN-10, China, } \\
\text { Japan, South Korea }\end{array}$ & $\begin{array}{l}\text { Chiang Mai Initiative on monetary and } \\
\text { financial co-operation implemented }\end{array}$ \\
\hline $\begin{array}{l}\text { ASEAN-Sout Korea } \\
\text { Comprehensive Economic } \\
\text { Partnership (including FTA) }\end{array}$ & $\begin{array}{l}\text { ASEAN-10, South } \\
\text { Korea }\end{array}$ & $\begin{array}{c}\text { Negotiations ongoing } \\
\text { (FTA outline negotiations begin } \\
\text { in early 2005) }\end{array}$ \\
\hline East Asia FTA & $\begin{array}{l}\text { ASEAN-10, China, } \\
\text { Japan, South Korea }\end{array}$ & $\begin{array}{l}\text { East Asia Study Group's measures for } \\
\text { establishing an East Asia FTA adopted, } \\
\text { further negotiations ongoing }\end{array}$ \\
\hline
\end{tabular}

Source: World Development Indicators Online Database (accessed on 2013-05-22).

12 Heiner, H. ASEAN and the ZOPFAN Concept. Singapose: Institute of Southeast Asian Studies, 2001, p. 183. 
Economic crisis in Asia has challenged these promises. The crisis has highlighted that the ASEAN's ability to deal with regional economic upheaval - which was already very limited - was contingent on its capacity to address the domestic policies of its members, the ASEAN's refusal to reconsider the principle of prevention of intervention, however, it effectively paralyzed the organization ${ }^{13}$.

\section{New institutional structures in Southeast Asia}

The creation of an Asian Monetary Fund (AMF) ${ }^{14}$ was proposed by Japan at the height of the economic crisis. This initiative was strongly opposed by the United States and the International Monetary Fund (IMF); China and South Korea also, initially, opposed a proposal that would enhance Japanese influence in the region. The idea was generally supported by the states of Southeast Asia, believing that the AMF would disburse loans without violation of the sovereignty of its Asian members, or would at least be sensitive to the political and economic circumstances of its client states.

The overall opposition to the initiative was too great, however, and Japan allowed it to fail. Nonetheless, the AMF idea continues to resurface in the aftermath of the crisis. China and South Korea now support the idea, and the newly-formed APT (which consists of the ASEAN states plus China, Japan and South Korea) may be considered as an embryonic AMF. Nonetheless, there remain huge obstacles, which can prevent from the establishment of such a regional organization, and by neoliberal theory most of them focused around strategic uncertainly and still prevailing tensions between the major Asian players.

Initially, the Manila Framework addressed the failure of the AFM idea. The Manila Framework allows the IMF disbursements to be supplemented with cooperative financial mechanism, enhances economic and technical cooperation, particularly on the purpose to strengthen domestic financial systems and regulatory capacities, and establishes a regional financial surveillance mechanism. The framework remains extremely limited; however, it lacks any formal structure or guaranteed funding ${ }^{15}$.

Over time, the APT states, supported by a better-institutionalized APT unit of economic monitoring and surveillance, will make decisions regarding requests for funding from the member states. Chaipravat hopes that in the near future, regional financial cooperation and institutionalization will have grown to a point where a common currency area will become a viable and realistic option for East Asia ${ }^{16}$. The

13 Sharma, S. Asia's Economic Crisis and IMF. Survival. 2000, 40 (2): 27-28.

14 Narinee, S. The Idea of an "ASIAN Monetary Fund": The Problems of Financial Institutionalism in the Asia Pacific. Asian Perspective. 2003, 27 (2): 65-67.

15 Chang, L. The Economics and Politics of Monetary Regionalism in Asia. ASEAN Economic Bulletin. 2001, 18 (1): 18-22.

16 Stubbs, R. ASEAN Plus Three: Emerging East Asian Regionalism? Asian Survey. 2002, 42 (3): 127-129. 
Ministers of Finance and the governors of the central banks will have their final word regarding the modalities, sizes, mechanisms, operating procedures, rules and regulations of East Asia's RFA ${ }^{17}$. Given the region's total of 1.9 billion people and its gross domestic product of 2 trillion dollars, the APT meetings are expected by some observers to form the basis for the emergence of a huge single market, possibly having a major impact on the creation of a tripartite world economic system ${ }^{18}$.

ASEAN Plus Three was established as the first regional institution that involves only the nations of East Asia on the purpose to promote political and economic cooperation at senior official, ministerial and heads-of-government levels ${ }^{19}$. The aim of the meetings is to enhance interactions and to foster closer relations through the increased cooperation and collaboration opportunities, thereby strengthening the promotion of mutual understanding, trust, good neighborhood and friendly relations, on the purpose to ensure peace, stability and prosperity in the region. However, these assessments are not beneficial when dealing with the real and serious political problems that complicate the development of the APT/RFA (a regional financial arrangement - RFA). Most of these problems originate in the region itself: unresolved tensions and rivalries between China and Japan complicate the matter of political leadership in the APT and block the development of an effective regional financial institution, at least in the near future ${ }^{20}$. Another concern is whether or not conditionality should be attached to APT/RFA loans. This concern is directly related to the issues of sovereignty.

Even the APT/RFA that sensitively responds to the political and economic realities of its member states will have to apply some conditionality in regard of its loans. Otherwise, the RFA will have to face the perspective of wasting considerable resources on states that might pursue economic policies and practices. The same considerations should be applied to any swap agreements that may now exist between Asian states. The perspective regarding determination of the terms by the APT in respect of its members is controversial in Asia because it could mean a major violation of the state sovereignty, however sensitive those conditions might be. The fact that this particular Asian institution would have to force conditionality was identified as a problem that was argued by Lee Kuan Yew, the former Prime Minister of Singapore, who declared that the IMF would need to continue its activities in Asia because the IMF was an external actor that could force the Asian states to make changes that no other Asian actor could demand ${ }^{21}$. The political volatility of one Asian state, or set of states, when determining the terms in respect of other countries, is the issue that loops back into

17 Bergsten, F. Towards a Tripartive World. Stanford Journal of East Asian Affairs. 2006, 1: 109.

18 Narinee, S., supra note 14, p. 74-77.

19 Mattli, W. Sovereignty Bargains in Regional Integration. International Studies Review. 2000, 2 (2): 80-85.

20 Narinee, S. Explaining ASEAN: Regionalism in Southeast Asia. Boulder, Colorado: Lynne Rienner, 2002, p. 185. Ibid., p. 186-188. 
the question of leadership: if the AMF was dominated by any of the regional powers, it would risk being regarded as an imperial extension of the dominant regional actors with the help of the weaker states of the region. This is especially sensitive issue, given the historical legacy of Japan and modern concerns with a rising China.

Based on the theory of neo-liberalism, a new regional structure that undertakes responsibility to solve the issues of sovereignty and weakness is the ASEAN Surveillance Process (ASP). The ASP was established on the purpose to oversee the economies of the ASEAN and to report as early as possible regarding any practices that might contribute to the future economic disruption. The ASP is still in the preliminary stage. However, its initial efforts to monitor the ASEAN economies have led to dissatisfaction from the side of many ASEAN states and they refused to share information with the ASP. The biggest fear of these states is that sensitive industrial and other information eventually will end up in the hands of competitors residing in other ASEAN countries. The states also lack the potential to force sharing of information by the companies that do not want to share it. The ASP has faced the limitations of state capacity and the concerns of ASEAN states regarding national competitive advantage ${ }^{22}$.

\section{Conclusions}

The lack of common interests leads to the absence of institutions and thus to instability and possible conflict. In contrast, the existence of institutions facilitates cooperation by limiting opportunist behaviour and by creating a network of interaction between states. By providing credible information, institutions reduce uncertainty. R. O. Keohane emphasizes that institutions can serve as the informational and signalling mechanisms that enable states to get more information about their interests, preferences and intentions of other states. Norms and rules developed by successful institutions regularize the behaviour of states belonging to them, making it more predictable. Institutions provide political space to build new coalitions on the purpose to try and to affect the emerging norms in the ways that are congruent with the interests of institutions and to keep a balance or at least to deflect the preferences and policies of the most powerful establishments. Institutions form the possibility for the region to emerge as a single actor in the international system.

Institutional capacity refers to the ability of regional institutions to make decisions. As well, it involves organs, rules and procedures, which are needed for implementation of these decisions. Also, the following are important: the capacity and efficacy to collect, collate and analyze data; the principles and the procedures

22 Furtado, X. Peering into Darkness: Evaluating the Prospects for an Economic and Financial Monitoring and Surveillance Mechanism in the Asia Pacific Region. Unpublished Paper [interactive]. 2001, p. 5. <http://www.iir.ubc.ca/Papers/Narine-WP41.pdf>. 
needed for making of decisions; the necessary subsidiary organs established for realization of these decisions; capabilities of command, control and communication; administrative and logistics support. In order to be effective, regional institutions have to command the respect and authority of the parties to the dispute in concern. In order to fulfill this need, regional institutions must be perceived to be impartial and strong, and with a good track record. Recognition, cooperation and support by other regional and global institutions may enhance credibility, as well. Lack of coordination and especially lack of competitive behavior by other institutions may undermine legitimacy and credibility.

Southeast Asian states should be wary of larger, global institutions if they are reluctant to sacrifice sovereignty to regional institutions. However, while dealing with the theory of neo-liberalism, it is stated that global and regional institutions have significant differences. In general, the larger state memberships and disparate interests encompassed by the global structures mean that they are less intrusive and less coherent than smaller regional structures are. As it was mentioned earlier, global institutions do not have the same historical baggage and do not face the same security issues as regional institutions. Moreover, Southeast Asian states need to participate in the global system for few reasons: they have little choice but to join the international regimes that define the fundamental rules of the system, while Southeast Asian states may have little control over global international regimes, they do have control over their self-created regimes, and they are unwilling to accord too much power to such regimes when there is no need to do this. These previously mentioned facts show that loose, consensus-oriented regional institutions of East Asia were well matched to their environments. However, inadequate position in a globalized world is proved by these institutions.

There is a difficult situation in the states of the Southeast Asia. However, theory of neo-liberalism suggests that successful cooperation requires a level of sovereign control and unification of national identity that many countries are still trying to develop. Being a strong, legitimate, sovereign state may be considered as an essential condition that should be ensured on the purpose to lay the foundation for the successful regional organization that operates in the emerging international environment. First of all, the states must firmly grasp the levers of sovereignty before loosening their hold. Moreover, the states may have to accept new responsibilities due to the new international forces. However, if the states lack capacity and the internal unity, which are essential in order to manage these new responsibilities, then they have to face even more complicated situations than before. Domestic structures can be promoted to collapse by globalization. It is said that the best perspective for the institutional development in Southeast Asia is associated with the fact that the states believe that regional institutions can be used fully in the process of state-building. 


\title{
References
}

Acharya, A. Constructing a Security Community in Southeast Asia. London: Rouledge, 2001.

Bergsten, F. Towards a Tripartive World. Stanford Journal of East Asian Affairs. 2006, 1.

Chaesung, Ch. Sovereingty: Dominance of the Westphalian Concept and Implications for Regional Security. Satnford, CA: Stanford University Press, 2003.

Chang, L. The Economics and Politics of Monetary Regionalism in Asia. ASEAN Economic Bulletin. 2001, 18 (1).

Cooper, R. N. Interdependence and Coordination of Policies. Amsterdam, 1985.

Furtado, X. Peering into Darkness: Evaluating the Prospects for an Economic and Financial Monitoring and Surveillance Mechanism in the Asia Pacific Region. Unpublished paper. 2001. <http://www.iir.ubc.ca/Papers/ Narine-WP41.pdf $>$.

Heiner, H. ASEAN and the ZOPFAN Concept. Singapore: Institute of Southeast Asian Studies, 2001.

Khoman, T. ASEAN: Conception and Evolution. Singapore: Institute of Southeast Asian Studies, 1992.

Kochane, O. R., and Hoffimann, E. (eds.). The New European Community: Decision-making and Institutional Change. Boulder, Colorado: Westview, 1991.
Kochane, O. R. Institutional Theory and Realist Challenge After the Cold War. Baldwin, D. (ed.). Neorealism and Neoliberalism. NY: Columbia UP, 1993.

Kochane, O. R. International Institutions and State Power. Boulder, Colorado: Westview, 1989.

Mattli, W. Sovereignty Bargains in Regional Integration. International Studies Review. 2000, 2 (2).

Narinee, S. Explaining ASEAN: Regionalism in Southeast Asia. Boulder, Colorado: Lynne Rienner, 2002.

Narinee, S. The Idea of an "ASIAN Monetary Fund": The Problems of Financial Institutionalism in the Asia Pacific. Asian Perspective. 2003, 27 (2).

Nischalke, T. Insights from ASEAN's Foreign Policy Co-operation: The "ASEAN Way", a Real Spirit or a Phantom? Contemporary Southeast Asia. 2000, 22 (1).

Petri, A. P. The East Asian Trading Block: An Analytical History. In: Frankel, J. A., and Kahler, M. (eds.). Regionalism and Rivalry. Japan and the United States in Pacific Asia. Chicago: Chicago UP, 1993.

Sharma, S. Asia's Economic Crisis and IMF. Survival. 2000, 40 (2).

Stubbs, R. ASEAN Plus Three: Emerging East Asian Regionalism? Asian Survey. 2002, 42 (3).

\section{REGIONINIS INSTITUCIONALIZMAS PIETRYČIŲ AZIJOJE}

\author{
Mindaugas Norkevičius \\ Vytauto Didžiojo universitetas, Lietuva
}

Santrauka. Straipsnyje aptariamos regionines tarptautinès institucijos Pietryčiu Azijos regione, kurios formuoja bendras regiono politikos taisykles, aktyviai dalyvauja sprendžiant regiono klausimus, susijusius su saugumu, ekonominio bendradarbiavimo ir politinemis regiono perspektyvomis. Regioninès tvarkos nuostatos yra susijusios su 
tarptautine sistema, kuriai atstovauja tokio pobūdžio institucijos vykdydamos regionine politiką. Dèl šių priežasčių institucijų poveikis gali turèti įtakos regionalizacijos procesu tęstinumui konkrečiame regione.

Pietryčiu Azijoje regionas formavosi kaip dekolonializacijos proceso padarinys, saugumo dinamikai regione itaka daré Šaltojo karo ideologine konfrontacija. Institucinio bendradarbiavimo sklaida regione paskatino tai, kad buvo daug tarpvalstybiniu konfliktų, vykstančiu valstybių viduje ir išeinančių už regiono ribų. Dél daugiapolés Pietryčiu Azijos regiono galios struktūros instituciju veikla tampa aktyvesne, jeigu tai susije su konkrečiu išorinių ar vidinių problemų sprendimo būdu suradimais. Institucijas galima laikyti vienomis svarbiausiomis politinemis priemonemis, formuojant konkrečia saugumo ir politine darbotvarkę. Regionines galios struktūros legitimavimas - viena iš instituciju funkcijų regionineje politikoje, o pačios institucijos tampa regionines tvarkos palaikymo priemone.

Nustatyta, kad regioniniu institucijų efektyvuma Pietryčiu Azijoje lemia reglamentuotas regionuiaktualių klausimusprendimas ekonominio bendradarbiavimo, transporto, aplinkosaugos, politinio dialogo vystymo srityse. Institucijos Pietryčiu Azijoje atlieka papildančios struktūros vaidmeni sprendimu priemimo procese, daro poveiki atskiroms nacionalinèms valstybèms, ju piliečiams ir kartu teikia siülymus ieškant konkretaus iškilusiu problemu sprendimo.

Straipsnyje analizuojamas regioninis institucionalizmas Pietryčiu Azijoje daugiausia demesio skiriant ASEAN organizacijai. ASEAN instituciniu struktūru formavimas vyko lètai, daugiau dèmesio buvo skiriama dialogui tarp regiono valstybių. Tačiau dabar instituciju vaidmuo, ju efektyvumas veikti regione ir už jo ribų tapo vienu iš svarbiausių ASEAN bruožų: kasmetiniai užsienio reikalų ministrų susitikimai, nacionaliniu sekretoriatu veikla valstybiu nariu sostinese, ASEAN sekretoriato, ivvairiu laikinujų ir nuolatiniu komitetu veiklos, valstybių viršūnių susitikimai. Išsiaiškinta, kad regioniniu instituciju efektyvumas pasireiškia politiniu ir saugumo konsultaciju skatinimu tarp regiono valstybiu, pasitikejimo kūrimu, preventyviosios diplomatijos raiška Azijos ir Ramiojo vandenyno regione.

Reikšminiai žodžiai: regionalizmas, regioninis institucionalizmas, Pietryčiu Azijos regionas, tarptautinés organizacijos.

Mindaugas Norkevičius, Vytauto Didžiojo universiteto Politikos mokslų ir diplomatijos fakulteto Politologijos katedros magistrantas. Mokslinių tyrimų sritys: regionai ir regionalizmas, Lietuvos diplomatija tarpukariu, Rytų ir Vidurio Europos valstybių užsienio politika, Lietuvos ir Lenkijos santykiai.

Mindaugas Norkevičius, Vytautas Magnus University, Faculty of Political Sciences and Diplomacy, Departament of Political Sciences, Master student. Research interests: regions and regionalism, Lithuanian diplomacy in the interwar period, foreign policy of the Eastern and Central European countries, relations between Lithuania and Poland. 